\title{
LEISHMANIA MEXICANA AMAZONENSIS ISOLATED FROM A PATIENT WITH FATAL MUCOSAL LEISHMANIASIS
}

There have been two previous references in the literature to mexicana type organisms isolated from patients with mucosal leishmanial granulomal ${ }^{16}$. We have recently identified a stock recovered from a patient with a severe mucosal lesion as Leishmania mexicana amazonensis using monoclonal antibodies and two techniques immunofluorescence (IFA) and radio immune binding assay ${ }^{2}$.

The patient (Reg. no 157049 ) was a 20 year old office clerk who had lived all his life in the town of J acobina, Bahia. At eleven years of age a skin ulcer, which left a typical scar on his right ankle, had healed after glucantime therapy. The nasal lesion had developed one year later and during the last eight years he had received various schemes of glucantime treatment (dose not recalled) and Amphotericin B to a total of 5 grams in a hospital in Salvador. Bahia.

As shown in the figure he had a severe destructive lesion of the nose with septal loss. Granulomatous inflammation involved the mouth, upper lip, pharynx and larynx. His voice was hoarse and weak. The lower lip and the tongue were spared. The case was remarkable for the degree of erythema of the nose and upper lip. Secondary bacterial infection with purulent secretion was present.

Amastigotes were easily visualised in smears and H\&E sections from the biopsies of mucosal granuloma and triturated material yielded the isolate on hamster inoculation. Although the IFA titre was 320 , the leishmanin skin test was repeatedly negative as were skin tests using DNCB, tuberculin and paracoccidiodin. He was treated with $10 \mathrm{mg} \mathrm{Sb} / \mathrm{Kilo-}$ gram/day of Pentostam for 30 days with considerable improvement and discharged to be followed up in out patients. Unfortunately he defaulted but returned 3 months later with a severely inflammed facial area and evidence of malnutrition. The IFA titre was the same at this time. Amphotericin B treatment was initiated but he developed bronchopneumonia, septicemia and died within a few days.

This patient is the only one of 20 with characterised mucosal isolates in our studies who had $L$. mexicana amazonensis; the rest had Leishmania braziliensis braziliensis. It appears that $L$. $m$.

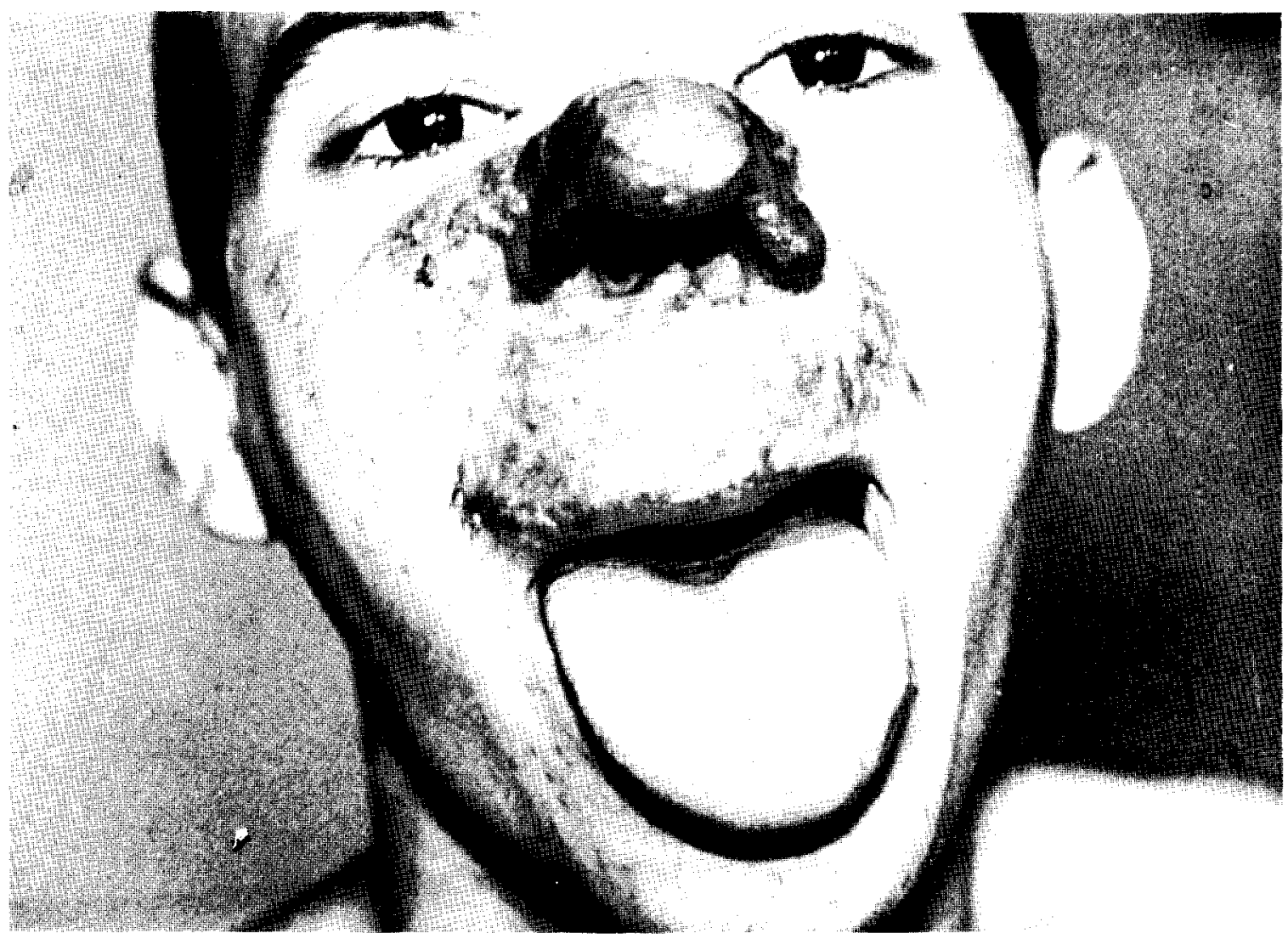

Patient R. 157049 Photograph at the time of admission 
amazonensis can metastasise to the mucosa after an initial skin lesion. However our patient had evidence of suppressed cell mediated immunity on skin testing although he was producing antibody. A negative leishmanin skin test is a bad prognostic sign as this patient well illustrates ${ }^{3}$. Associated malnutrition could explain the impaired cellular immune responses and the unusual behavior of $L$. m. amazonensis in this patient. Walton et al. ${ }^{6}$, explained another mucosal lesion caused by L. mexicana on the grounds that the patient had received prior radiation therapy for neoplastic disease.

Nevertheless it was disappointing that he died. Today with better knowledge of how to handle maximal antimonial therapy 5 we would not use such a low continuous dose for only 30 days. We have cured recalcitrant disease with as long as 85 days continuous therapy at double the dose this patient received with a favourable outcome ${ }^{4}$. The fact that he responded well to $10 \mathrm{mg} \mathrm{Sb} / \mathrm{kilo} /$ day for 30 days indicates that if we had adopted such a regimen he might well be alive today.

\section{REFERENCES}

1. Barral A, Petersen EA, Sacks DL, Neva FA. Late metastatic leishmaniasis in the mouse. American Journal of Tropical Medicine and Hygiene 32: 277-285, 1983.
2. McMahon Pratt D, Jaffe CL, Grimaldi Jr. G. Ripplication of monoclonal antibodie to the classificetion of Leishmania species. In: Morel CM (ed) Genes and antigens of parasites. A laboratory manual. 2nd edition. UNDP/World Bank/TDR. Rio de Janeiro, 1983.

3. Marsden PD, Llanos-Cuentas EA, Lago EL, Cuba CAC, Barreto AC, Costa JM, Jones TC. Human mucocutaneous leishmaniasis in Três Braços, Bahia, Brasil. An area of Leishmania braziliensis braziliensis transmission. III. Mucosal disease: Presentantion and initial evolution. Revista da Sociedade Brasileira de Medicina Tropical 17: 179-186, 1984.

4. Marsden PD, Sampaio RN, Carvalho EM, Veiga JPT. Costa JLM, Llanos-Cuentas EA. High continuous antimony therapy in two patients with unresponsive mucosal leishmaniasis. American Journal of Tropical Medicine and Hygiene 34: 710-713, 1985.

5. Sampaio RNR. Tratamento hospitalar de leishmaniose cutâneo-mucosa. Tese de mestrado. Universidade Federal de Minas Gerais, Belo Horizonte. 1984.

6. Walton BC, Intermill RW, Hajduk ME. Differences in biological characteristics of three Leishmania isolates from patients with espundia. American Journal of Tropical Medicine and Hygiene 26:850-855, 1977.

\author{
Raimunda N. Sampaio* \\ Philip D. Marsden * \\ Elmer A. Llanos Cuentas* \\ Cesar A. Cuba Cuba * \\ Gabriel Grimaldi Jr. **
}

\footnotetext{
* Núcleo de Medicina Tropical e Nutrição, Universidade de Brasilia, Brasilia-DF, Brasil and ** Centro de Microscopia Eletrònica Fundação Instituto Oswaldo Cruz, Rio de Janeiro - Brasil.
} 